\title{
Quality of Deep Frying Oil as Affected By the Type of Foods and Total Frying-Use Time
}

\author{
Rofida F. Moftah, M. R. A. Rashwan, A. H. Khalifa and F. A. El-Feshawy \\ Food Science and Technology Department, Faculty of Agriculture, Assiut University, \\ Assiut, Egypt
}

\begin{abstract}
:
Some quality parameters included, free fatty acids, peroxide value, iodine value, fatty acid composition as well as degree of color darkening were evaluated for mixed vegetable oil during 16 hours at $180 \mathrm{C}^{\circ}$ of deep-frying process. Both of potato and chicken were used as frying materials for 10 and $15 \mathrm{~min}$,, respectively. The results indicated that, there were gradually increase of free fatty acids and decrease of iodine value with the two types of the used foods with increasing of deep frying process time. Peroxide value, recorded initially an increase, then decreased after 14 and 6 hours of frying process of potato and chicken, respectively. During the deep frying process, the total unsaturated fatty acid content of the used oil was decreased while the total saturated fatty acid content was increased. Darkening degree of the used oil color was increased by increasing the use-time of frying process with slightly high of color darkening in case of chicken compared to that of potato frying.
\end{abstract}

Keywords: Deep-frying oil, Quality parameters- Fatty acid composition- ColorPotato- Chicken.

Received on:18/4/2013

Referees: Prof. Samy I. M. Elsyiad
Accepted for publication on: 20/4/2013

Prof. Mohamed B. E. Omar 


\section{Introduction:}

Fats and oils play important functional and sensory roles in fried food products. However, deep fat frying process is an important operation used by food industry and consumers (Varela, 1988). It can be defined as a process of cooking food by immersing them in edible oil at a temperature about 120 to $180 \mathrm{C}$ (Vitrac et al., 2000) and Torezan, 2005). Frying is used in homes, restaurants, and various segments of food industry (Brooks, 1991). Today, numerous processed foods are deep-fried because of the unique flavor-texture combination imparted to the food (Varela, 1988), and preparing tasty foods that have soft and moist interior together with the crispy crust (Garcia et al., 2001). In the presence of oxygen, moisture, elements and free radical, physiochemical reaction such as thermoxidation, hydrolysis, polymerization, isomerization or cyclization take place at high temperature of frying process, thus leading to the decomposition of frying oil as well as affecting the quality of oil and frying product (Andrikopoulos et al., 2002). Moreover deep frying process depend on several factors such as replacement with fresh oil, frying condition, original quality of frying oil, food material, type of fryer and frying temperature (Sanchez-Muniz et al., 1992). Usually many oils can be used for frying, e.g. palm oil, corn oil, cotton oil, soya oil, canola oil and sunflower oil (Valenzuela et al., 2003). On other hand, several different oils many be blended to get a healthy oil mixture. In Egypt many people use mixed oils in frying process.

However, the quality of the oil used in the frying operation becomes part of the food we eat and is, of course the major factor in the quality and nutritional value of the food we eat ( Rossell, 2001). Thus, the objective of this study was to evaluate the quality of mixed vegetable oil as affected by two types of food during 16 hours of deep frying process.

\section{Materials and Methods:}

\section{Materials:}

Refined mixed oil of sunflower, cotton seed and soya been, "Marmar" produced by Nile oil and Detergent Company was purchased from Bany qurra village. Potatoes and chicken were obtained from local market of Assiut city.

\section{Sample preparation:}

Fresh potatoes were peeled and sliced to a thickness of $1.5 \mathrm{~cm}$. and $7 \mathrm{~cm}$. in length using a mechanical slicer. Fresh chicken pieces were cut to about 200 gram in weight using a knife. The Batches of chicken scrupulously washed and cleaned.

\section{Frying process:}

The potato slices and raw chicken pieces were deep-fried independently, each in 1.5 Liter of refined mixed oil. When the oil temperature reached $180^{\circ} \mathrm{C}$, The potato slices and chicken pieces were fried for 10 and $15 \mathrm{~min}$. intervals respectively until 16 hours. At the end of each 2 hours, $100 \mathrm{ml}$ of the oil was taken from the fryer and analyzed for its physicochemical parameters.

\section{Chemical analysis:}

Acid value was determined according to the A.O.A.C. (2000) as follows: A known weight $(10 \mathrm{~g})$ of the oil was dissolved in a neutral ethyl alcohol $(50 \mathrm{ml})$. The mixture was boiled on a water bath for $2 \mathrm{~min}$ and then titrated with potassium hydroxide solution $(0.1 \mathrm{~N})$ in the presence of phenolphthalein as an indica- 
tor. Acid value is expressed as $\mathrm{mg} \mathrm{KOH}$ required to neutralize the acidity in one gram oil.

The peroxide value was determined according to A.O.A.C. (2000). A known weight of the oil sample $(1 \mathrm{~g})$ was dissolved in a mixture consisting of glacial acetic acid: chloroform $(10 \mathrm{ml}, 3: 2, \mathrm{v} / \mathrm{v})$ then freshly prepared saturated potassium iodide solution $(1 \mathrm{ml})$ was added followed by distilled water $(30 \mathrm{ml})$ and then titrated slowly with sodium thiosulphate solution $(0.01 \mathrm{~N})$ in the presence of starch solution (1\%) as an indicator. Peroxide value is expressed as milliequivalent peroxides $/ 1 \mathrm{~kg}$ oil.

The iodine value was determined using the Hanus method as described in A.O.A.C. (2000). A known weight of oil (0.25-0.5 g) was dissolved in chloroform $(10 \mathrm{ml})$, then Hanus iodine $\left(\mathrm{I}_{2}+\mathrm{Br} / \mathrm{ACOH}\right)$ solution $(25 \mathrm{ml})$ was added and left in the dark for $30 \mathrm{~min}$. Potassium iodide solution $(10 \mathrm{ml}, 15 \%)$ was added followed by freshly distilled water $(100 \mathrm{ml})$ and the excess iodine was titrated by sodium thiosulphate $(0.1 \mathrm{~N})$ until the yellow color of solution had almost disappeared. Titration was continued after adding few drops of starch as an indicator until the blue color had entirely disappeared. Iodine value is expressed as grams of $\mathrm{I}_{2}$ absorbed by $100 \mathrm{~g}$ oil.

Fatty acid composition was methylated following the AOCS Official Method. The resulting fatty acid methyl esters (FAME) were analyzed on Trace GC Ultra gas chromatograph (Thermo Electron Corporation, Rodano, Italy) using a Trace TR-FAME fused silica capillary column (100 m $90.25 \mathrm{~mm} 90.25$ $1 \mathrm{~m}$; ThermoFisher Scientific, Waltham, MA, USA). Hydrogen was used as the carrier gas with a flow rate of $1.5 \mathrm{~mL} \mathrm{~min}-1$. The column temperature was programmed from 70 to $160 \mathrm{C}$ at $25 \mathrm{C} \mathrm{min}-1$ and held for $30 \mathrm{~min}$, and further programmed to $210 \mathrm{C}$ at $3 \mathrm{C} \mathrm{min}^{-1}$. Starting and final temperatures were held for 5 and $30 \mathrm{~min}$, respectively. Split less injection was made using a PTV injector. Detector temperature was set at 250C. FAME samples, $1 \mu \mathrm{L}$, were injected with an AS 3000 autosampler (Thermo Electron Corporation, Rodano, Italy). Fatty acids were identified by comparison of retention time with authentic standards.

The color: Frozen oil samples were melted by placing them at $60^{\circ} \mathrm{C}$ in an oven until completely melts. The liquid samples were placed into 1 inch cell and using a Lovibond Tintometer Model E (Salisbury, England) the color was determined at $30^{\circ} \mathrm{C}$ by achieving the best possible match with the standard color slides of red, yellow and blue indices (PORIM, 1995).

\section{Results and Discussion: \\ Changes in free fatty acids}

Data indicated the changes in free fatty acids (FFAs) of the used oil are shown in Table (1) and Fig. (1). With increasing of deep frying process time, there were gradually increase of free fatty acids with the two types of fried foods. The increase of acid value may be due to hydrolysis of the oil. On other hand the free fatty acids of the used oil with chicken frying was slightly higher than that of potato case by the end of frying time and that may be due to some migration of chicken fat to the used oil, which was more unsaturation and faster to hydrolysis and oxidation. However, the free fatty values reached 0.57 and $0.66 \mathrm{mg} \mathrm{KOH} / \mathrm{g}$ oil for potato and chicken frying, respectively after 16 hours of frying process. The increase in free acids value of frying oil during frying was also observed by 
(Augustin et al., 1987; Yoon et al., 1987 and Zhang and Addis, 1990). Moreover, the maximum acid index of edible oils is $15 \mathrm{mg} \mathrm{KOH} / \mathrm{g}$ of oil as reported by (Krishnamurthy, 1982).

Table 1: Free fatty acids value of oil during deep frying of potato and chicken.

\begin{tabular}{|c|c|c|}
\hline \multirow{2}{*}{$\begin{array}{c}\text { Time of frying } \\
\text { (Hours) }\end{array}$} & \multicolumn{2}{|c|}{$\begin{array}{c}\text { Free fatty acids } \\
\text { (mgKOH/g oil) }\end{array}$} \\
\cline { 2 - 3 } & Potato & Chicken \\
\hline $\mathbf{0}$ & 0.193 & 0.193 \\
\hline $\mathbf{2}$ & 0.196 & 0.195 \\
\hline $\mathbf{4}$ & 0.216 & 0.235 \\
\hline $\mathbf{6}$ & 0.296 & 0.276 \\
\hline $\mathbf{8}$ & 0.314 & 0.353 \\
\hline $\mathbf{1 0}$ & 0.377 & 0.392 \\
\hline $\mathbf{1 2}$ & 0.396 & 0.465 \\
\hline $\mathbf{1 4}$ & 0.487 & 0.552 \\
\hline $\mathbf{1 6}$ & 0.572 & 0.662 \\
\hline
\end{tabular}

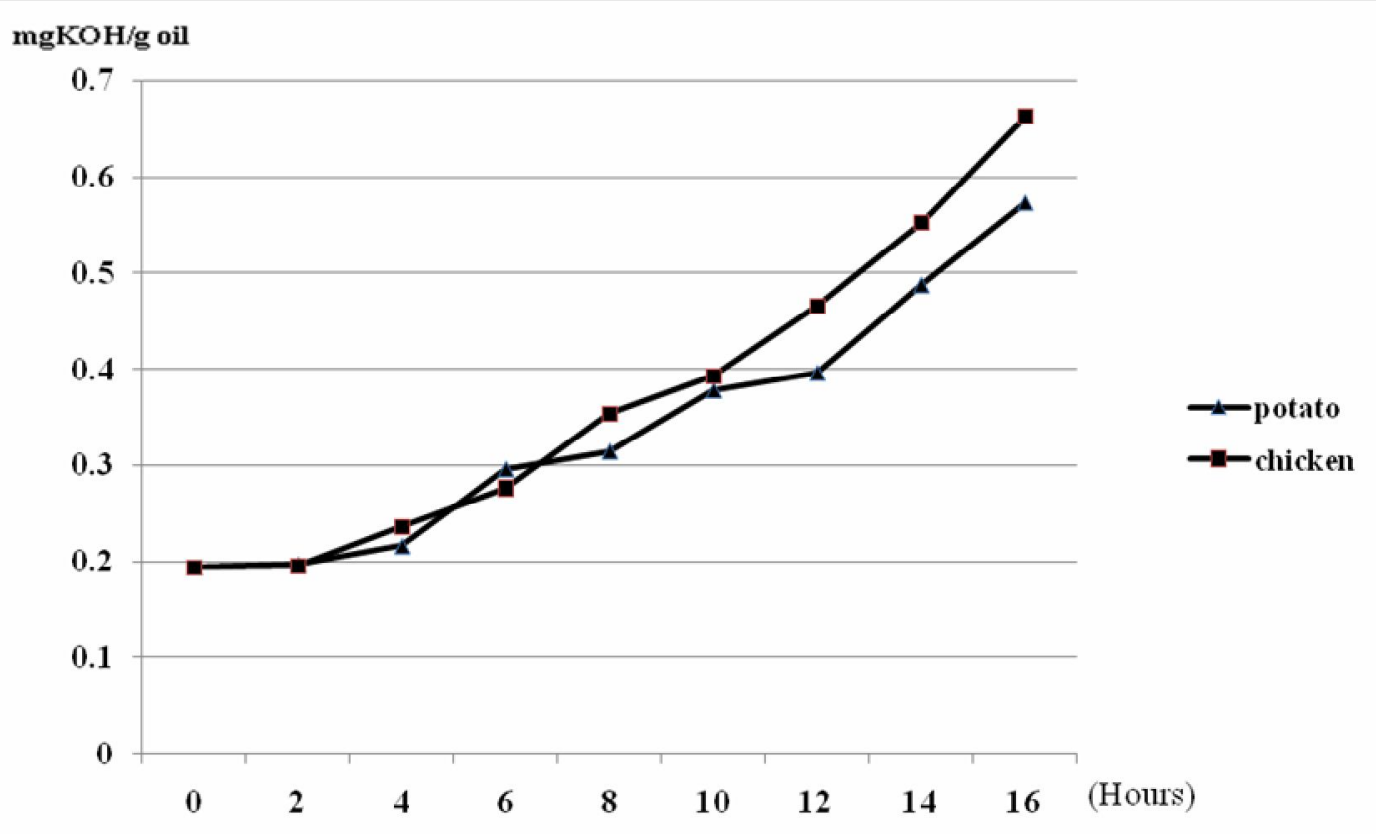

Fig. 1: Changes in free fatty acids of oil during deep frying of potato and chicken

Changes in peroxide value ( $\mathrm{PV})$ :

Data presented in Table (2) and Fig. (2) revealed the changes of peroxide value of the used oil after 16 hours of frying of potato and chicken. Initially, there were an increase of peroxide values, then decreased after 14 hours in case 
of potato and after 6 hours in case of chicken as shown in Table (2). As reported by (Weiss, 1970; Davidek et al., 1990), the peroxides are unstable and will destruct to other secondary products. Decomposition of the peroxides to produce carbonyl and aldehydeic compounds under deep-fat frying operation is one of the reasons why peroxide value decreased (Chu et al., 2001). However, during frying, the changes in peroxide value not related to the duration of frying, but were dependent pn the rate of formation and breakdown of oxidation products. Furthermore, frying of chicken with aldehydes (products of lipid oxidation) will increase Millard reactions and Strecker degradation, so peroxides, being a lipid oxidation product, will not be calculated for in the peroxide value of the oil (Davidek et al., 1990).

Table 2: Peroxide value of oil during deep frying of potato and chicken.

\begin{tabular}{|c|c|c|}
\hline \multirow{2}{*}{$\begin{array}{c}\text { Time of frying } \\
\text { (Hours) }\end{array}$} & \multicolumn{2}{|c|}{$\begin{array}{c}\text { Peroxide value } \\
\text { (meq/Kg oil }\end{array}$} \\
\cline { 2 - 3 } & Potato & Chicken \\
\hline $\mathbf{0}$ & 3.933 & 3.933 \\
\hline $\mathbf{2}$ & 4.127 & 4.230 \\
\hline $\mathbf{4}$ & 4.90 & 4.960 \\
\hline $\mathbf{6}$ & 5.357 & 5.240 \\
\hline $\mathbf{8}$ & 4.947 & 4.943 \\
\hline $\mathbf{1 0}$ & 5.923 & 4.557 \\
\hline $\mathbf{1 2}$ & 6.863 & 4.140 \\
\hline $\mathbf{1 4}$ & 7.157 & 3.853 \\
\hline $\mathbf{1 6}$ & 6.340 & 3.243 \\
\hline
\end{tabular}

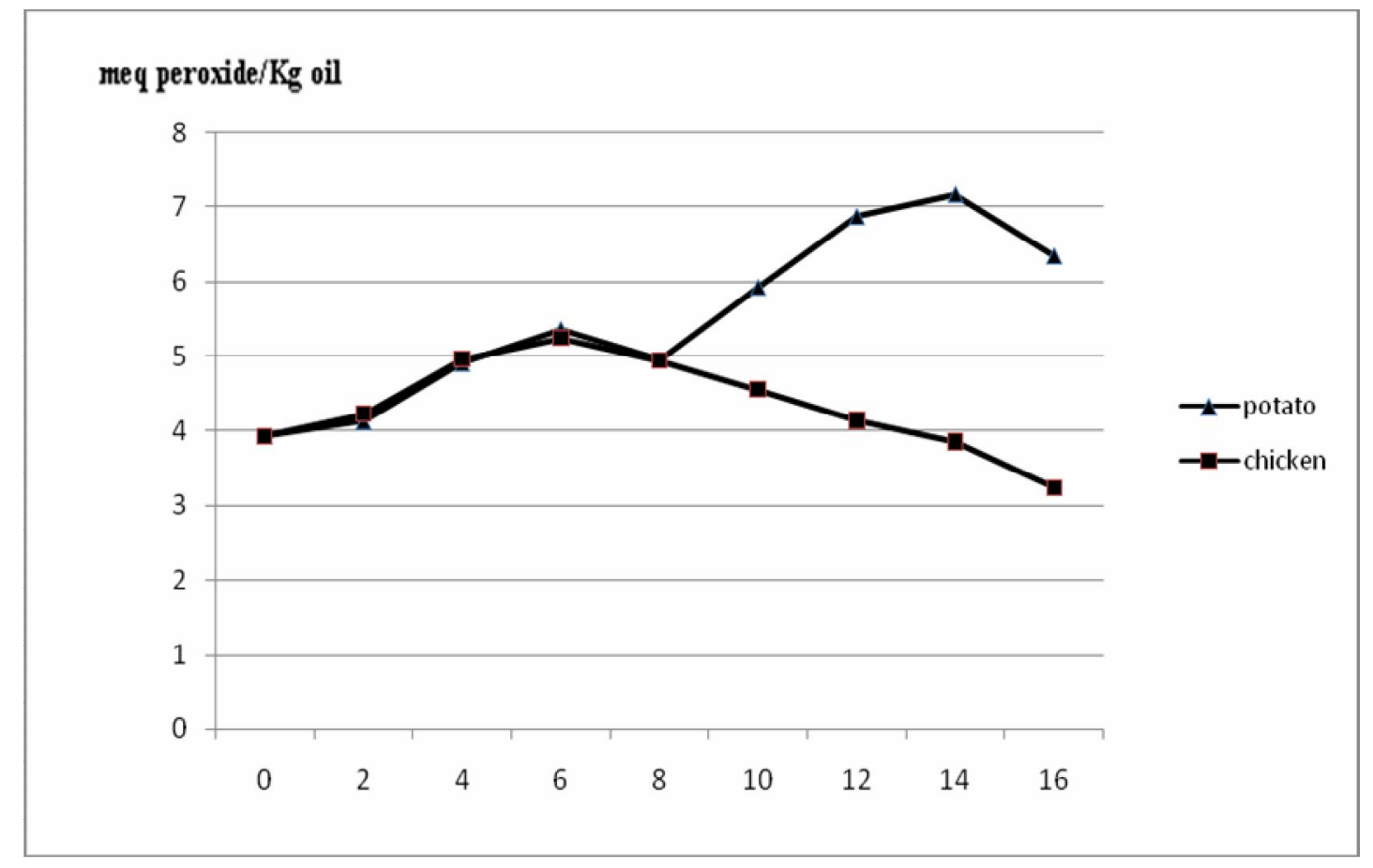

Fig. 2: Changes in peroxide value of oil during deep frying of potato and chicken.

Changes in iodine value (IV): 
The changes of iodine value in the used oil are presented in Fig. (3). The iodine value was decreased from about $125 \mathrm{gI}_{2} / 100 \mathrm{~g}$ oil to about 115 and 110 $\mathrm{gI}_{2} / 100 \mathrm{~g}$ oil for the oil used with deep frying of potato and chicken, respectively. The decrease of iodine value can be attributed to the destruction of double bonds by oxidation and polymerization (Chu et al., 2001). Moreover, Iskander, (1992), reported that, the decrease in iodine value during frying could be attributed to the formation of fatty acids which varies in their degree of unsaturation or to the distribution of the double bonds in the oil. However, the decrease of iodine value of the oil used for chicken frying was faster than that of potato frying as shown in Fig. (3) and that could be due to the difference in the constituent of the two products. Chicken product has more fat content than potato and the fat of chicken is more unsaturation. During frying process, some of chicken fat migrate to the oil (Mountney, 1976). Moreover, during the frying, permeable unsaturated fatty acids are rapidly oxidized to saturated fatty acids, leading to a faster decrease in iodine value (Mazza and Qi, 1992).

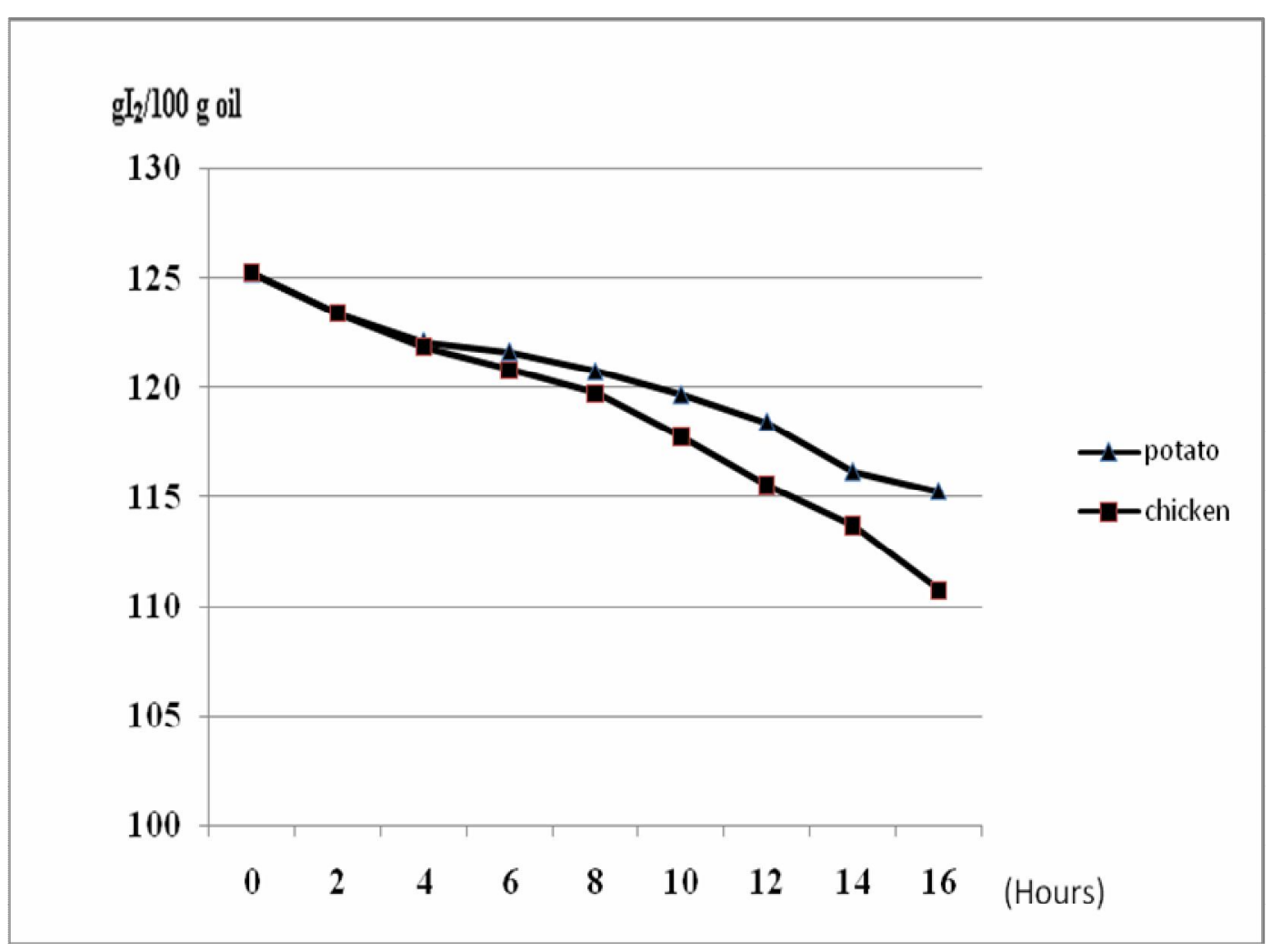

Fig. 3: Changes in iodine value of oil during deep frying of potato and chicken. 


\section{Changes in fatty acid composition:}

The changes in fatty acid composition during deep-fat frying of potato and chicken are shown in Table (3) and (4), respectively. The most prominent fatty acids in the used oil were linoleic acid (55.3), oleic acid (22.7), palmtic acid (10.4), linolenic acid (5.2) and stearic acid (4.4\%) of total fatty acids. The total saturated fatty acids constituted about $15.9 \%$, while total unsaturated fatty acids recorded about $84.2 \%$ of total fatty acids content.

During frying of potato and chicken, there was a decrease in both of the linolenic acid and linoleic acid contents in accordance with (Sulieman et al, 2006 and Alireza et al, 2010), whereas the palmitic acid content was increased with a prolonged frying time same as observed by Alireza et al, 2010. Data in Table (3) and (4) revealed that, with increase of frying time, total saturated fatty acids content was increased, while total unsaturated fatty acids content was decreased. Arroyo et al., (1995) pointed out that heat treatment of fats induce modification of fatty acids with two or three double bonds. However, the decrease of unsaturated fatty acids content reflects the decrease of iodine value by increasing frying time as shown in Fig. (3).

Table 3: Changes of fatty acids composition (\% of total fatty acids) of the used oil during frying of potato.

\begin{tabular}{|l|c|c|c|c|c|c|}
\hline \multirow{2}{*}{ Fatty acids } & \multirow{2}{*}{$\begin{array}{c}\text { Carbond } \\
\text { chain }\end{array}$} & \multicolumn{5}{c|}{ Frying time (hours) } \\
\cline { 4 - 7 } Myristic acid & Control & $\mathbf{4}$ hrs & $\mathbf{8}$ hrs & $\mathbf{1 2 h r s}$ & $\mathbf{1 6 h r s}$ \\
\hline Palmtic acid & $\mathrm{C} 16: 0$ & 10.371 & 10.555 & 11.773 & 10.939 & 11.579 \\
\hline Plamitoleic acid & $\mathrm{C} 16: 1$ & 0.825 & 0.723 & 0.295 & 0.203 & 0.106 \\
\hline Margaric acid & $\mathrm{C} 17: 0$ & 0.143 & 0.275 & 0.624 & 0.719 & 0.831 \\
\hline Stearic acid & $\mathrm{C} 18: 0$ & 4.36 & 6.569 & 6.487 & 6.859 & 7.347 \\
\hline Oleic acid & $\mathrm{C} 18: 1$ & 22.663 & 22.374 & 21.197 & 21.622 & 21.109 \\
\hline Linoleic acid & $\mathrm{C} 18: 2$ & 55.305 & 53.001 & 52.702 & 53.271 & 53.105 \\
\hline Linolenic acid & $\mathrm{C} 18: 3$ & 5.218 & 5.299 & 5.217 & 4.868 & 4.222 \\
\hline Arachidic acid & $\mathrm{C} 20: 0$ & 0.36 & 0.38 & 0.32 & 0.36 & 0.34 \\
\hline Gadoleic acid & $\mathrm{C} 20: 1$ & 0.196 & 0.174 & 0.105 & 0.104 & 0.107 \\
\hline Behenic acid & $\mathrm{C} 22: 0$ & 0.399 & 0.447 & 0.488 & 0.473 & 0.484 \\
\hline Lignoceric acid & $\mathrm{C} 24: 0$ & 0.121 & 0.141 & 0.149 & 0.152 & 0.172 \\
\hline \multicolumn{1}{|c|}{ Total Sat. FA } & $\mathbf{1 5 . 8 5 3}$ & $\mathbf{1 8 . 8 6}$ & $\mathbf{2 1 . 4 7 9}$ & $\mathbf{1 9 . 5 0 1}$ & $\mathbf{2 0 . 3 5 6}$ \\
\hline Total Unsat. FA & $\mathbf{8 4 . 2 0 7}$ & $\mathbf{8 1 . 1 4}$ & $\mathbf{7 8 . 5 2 1}$ & $\mathbf{8 0 . 4 9 9}$ & $\mathbf{7 9 . 6 4 4}$ \\
\hline
\end{tabular}


Table 4: Changes of fatty acids composition (\% of total fatty acids) of the used oil during frying of chicken.

\begin{tabular}{|c|c|c|c|c|c|c|}
\hline \multirow{2}{*}{ Fatty acids } & \multirow{2}{*}{$\begin{array}{c}\text { Carbond } \\
\text { chain }\end{array}$} & \multicolumn{5}{|c|}{ Frying time (hours) } \\
\hline & & Control & 4 hrs & 8 hrs & $12 \mathrm{hrs}$ & 16hrs \\
\hline Myristic acid & $\mathrm{C} 14: 0$ & 0.099 & 0.115 & 0.108 & 0.133 & 0.113 \\
\hline Palmtic acid & C16:0 & 10.371 & 11.443 & 11.057 & 11.755 & 11.085 \\
\hline Plamitoleic acid & C16:1 & 0.825 & 0.626 & 0.55 & 0.395 & 0.308 \\
\hline Margaric acid & C17:0 & 0.143 & 0.372 & 0.081 & 0.076 & 0.241 \\
\hline Stearic acid & C18:0 & 4.36 & 5.055 & 6.316 & 6.758 & 7.817 \\
\hline Oleic acid & C18:1 & 22.663 & 21.917 & 21.545 & 21.49 & 21.092 \\
\hline Linoleic acid & C18:2 & 55.305 & 53.913 & 54.311 & 53.396 & 53.513 \\
\hline \multicolumn{2}{|c|}{ Unknown } & 0.121 & 0.461 & 0.056 & 0.0587 & 0.066 \\
\hline Linolenic acid & C18:3 & 5.218 & 5.157 & 5.04 & 4.974 & 4.85 \\
\hline Arachidic acid & C20:0 & 0.36 & 0.342 & 0.347 & 0.365 & 0.352 \\
\hline Gadoleic acid & C20:1 & 0.196 & 0.178 & 0.167 & 0.182 & 0.179 \\
\hline Behenic acid & $\mathrm{C} 22: 0$ & 0.399 & 0.429 & 0.422 & 0.419 & 0.442 \\
\hline \multicolumn{2}{|c|}{ Total Sat. FA } & 15.732 & 17.756 & 18.331 & 19.506 & 20.05 \\
\hline \multicolumn{2}{|c|}{ Total Unsat. FA } & 84.207 & 81.791 & 81.613 & 80.437 & 79.942 \\
\hline
\end{tabular}

\section{Changes of oil color:}

The changes of the used oil color during frying process are shown in Fig. (4). The color of the used oil was gradually darkened by increasing the frying time. Darkening of the oil may be due to leaching of pigments from the food into the oil (Singh, et al. 1996); a Maillard reactions, leading to the formation of brown pigment and increase absorption of blue light by conjugated double bonds, giving orange and brown colors to the oil (Kress-Rogers, et al. 1990) and an increase in polymer content (Moreira, et al. 1996). Darkening degree of the oil used for chicken frying was slightly high compared to that of potato frying (Fig. 4). The high degree of darkening in case of chicken could probably be attributed to the higher degree of Maillard browning in chicken. Further, particles from chicken pieces could have become charred to produce some fat-soluble colored compounds, which darkened the oil. However, the color index of vegetable oils increased with frying time, as a result of brown pigments from the fried products dissolving into the frying oil and a combined effect of oxidation and polymerization of unsaturated fatty acids in frying medium (Irwandi et al. 2000). 


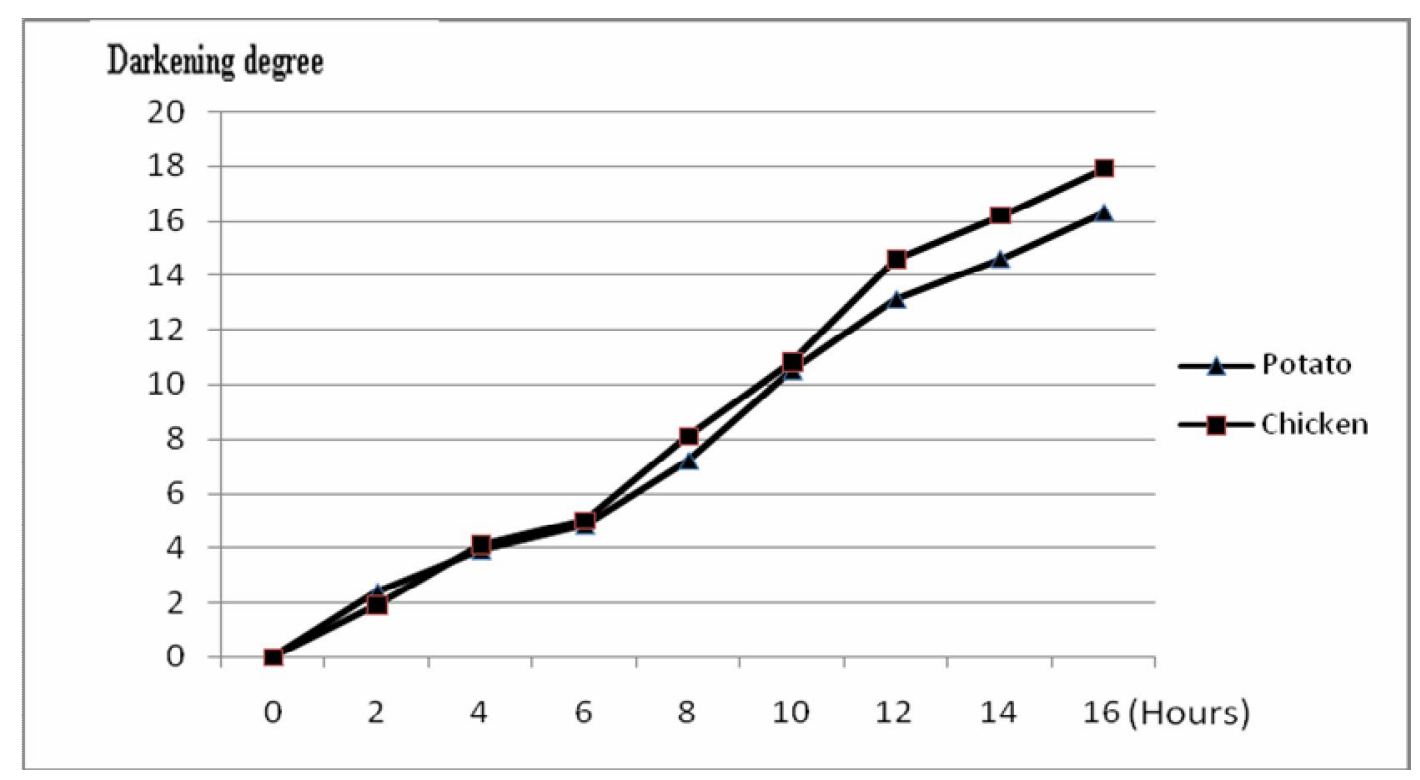

Fig. 4: Changes in color of oil during deep frying of potato and chicken.

\section{Conclusion :}

Some deterioration of the oil quality properties accrued by deep frying process and the type of fried food as well as a long of time-use are necessary factors in this side

\section{References:}

A.O.A.C. (2000): Official Methods of Analysis of the Association of Official Analytical Chemists, 14th Ed. The Association: Washington, DC.

Alireza, S.; Tan, C. P.; Hamed, M. and Che Man, Y. B. (2010): Effect of frying process on fatty acid composition and iodine value of selected vegetable oils and their blends International Food Research Journal 17: 295-302

Andrikopoulos, N. K.; Kalogeropoulos, N.; Falirea, A. and Barbagianni, L. M. N. (2002): Performance of virgin olive oil and vegetable shortening during domestic deep-frying and pan-frying of potatoes. Int. J. food sci. Technil., 37: 177-190.

Arroyo, R.; Cuesta, C.; Sanchez, J. and Sanchezmuniz, F. (1995): High performance size exclusion chromatography of palm olein used for frying. Fat. Sci Technol. 97, 292-296.

Augustin, M. A.; Asap, T. and Heng, L. K. (1987): Relationships between measurements of fat deterioration during heating and frying in RBD olein. J. Am. Oil Chem. Soc. 64, 1670-1675.

Brooks, D. D. (1991): Some Perspective on Deep-Fat Frying. INFORM 2, 10911095.

Chu, B. S.; Ghazali, H. M.; Che Man, Y. B.; Yousef, S. and Yousef, M. S. A. (2001): Performance of a lipase- catalyzedtoring transesterified palm kernel olein and palm stearin blend in frying banana chips. J Food chem, 74:21-33.

Davidek, J.; Velisek, J. and Pokorny, J. (1990): Developments in food science. Chemical changes during food processing. Vol. 21, pp. 196-223. Elsevier, Oxford.

Garcia, M. A.; Ferrero, C.; Be'rtola, N.; Martino, M. and Zaritsky, N. (2002): Edible coatings from cellulose derivatives to reduce oil update in fried products. Innovative Food Science and Emerging Technologies 3:391_397. 
Irwandi, J.; Che Man, Y. B.; Kitts, D. D.; Bakar, J. and Jinap, S. (2000): Synergies between plant antioxidant blends in preventing peroxidation reactions in model and food oil system. J. Am. Oil Chem. Soc. 77, 945-950.

Iskander, M. H. (1992): Some physical and chemical changes in corn and palm oils during frying eggplant and potato. La Rivista Italiana Delle Sostanze Grasse Vol. XIX, p. 15-19.

Kress-Rogers, E.; Gillat, P. N. and Rossell, J. B. (1990): Development and evaluation of a novel sensor for in situ assessment of frying oil quality. Food Control 1 (3), 163-178

Krishnamurthy, R. G. (1982): cooking oils, salad oils and dressings. In Baileys industrial oil fat products. (Vol.2, $4^{\text {th }}$ ed.). john Wiley and Son, 315-341, New York

Mazza, G. and Qi, H. (1992): Effect of after cooking darkening inhibitors on stability of frying oil and quality of French fries. Journal of the American oil chemist society, 69, 847-853.

Moreira, R.; Yi, C. T. and Sun, X. (1996): Total frying-use time effects on soybean-oil deterioration and on tortilla chip quality. International Journal of Food science and technology, 31, 287- 294.

Mountney, G. J. (1976): Poultry product technology. Pp. 53-57. Avi publishing, Westport. CN.

PORIM, (1995): PORIM Test Methods Ed. 1. Malaysia: Palm Oil Research Institute of Malaysia.

Rossell, J. B. (2001): Frying improving quality. 1st edn. CRC Press LLC, North America, Pp74- 150.

Sanchez-Muniz, F. J.; Viejo, J. M. and Medina, R. (1992): Deep-frying of sardines in different culinary fats. Changes in the fatty acid composition of sardines and frying fats. J Agric Food Chem 40: 2252-2256.

Singh, P.; Vijayan, J. and Slaughter, D. C. (1996): Optical properties of corn oil during frying. International Journal of Food Science and Tech-nology 31:353-358 .

Sulieman, A. M.; El-Makhzangy, A. and Ramadan, M. F. (2006): antiradical performance and physicochemical Characteristics of vegetable oils upon frying of French Fries: a preliminary comparative EJEAFChe, 5 (4), [1429-1441].

Torezan, G. A. P. (2005): Develoment of the combined process of osmotic dehydration-frying chips to obtain mango. Ph.D. Thesis, state University of Campinas, Campinas.

Valenzuela, A.; Sanhueza, J. and Nieto, S. (2003): Cholesterol oxidation: health hazard and the role of antioxidants in prevention. Biological Research, 36, 291-302. doi:10.4067/S0716-

Varela, G. (1988): Current facts about the frying of food. In: Frying of food: Principles, changes, new approaches (Ed. by G. Varela, A. E. Benker \& J. D. Morton), pp. 9-25. Chichester, England: Ellis Horwood.

Vitrac, O.; Trystam, G. and Raoult-Wark, A. L. (2000): Deep-fat frying of food: Heat and mass transfer, transformations and reactions inside the frying material. Eur. J. Lipid Technol., 102: 529-538.

Weiss, T. J. (1970): Food oils and their uses. Pp. 26-35, 47-48, 108-121. Avi publishing. Westport. CN. 
Yoon, S. H.; Kim, S. K.; Kim, K. H. and Kwon, W. T. (1987): Evaluation of physicochemical changes in cooking oil during heating. J. Am. Oil Chem. Soc., 64: 870-876.

Zhang, W. B and Addis, P. B. (1990): prediction of level of cholesterol oxides in heated tallow by dielectric measurements. J. food Sci. 55, 1673-1675. 
جودة زيت التحمير العميق ومدي تأثيره بنوعية الطعام وطول فترة الأستخدام

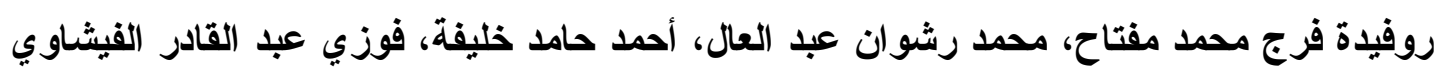

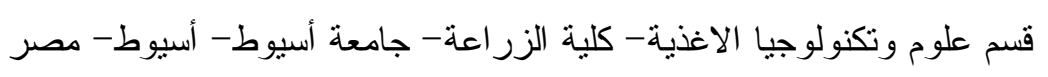

تم تقييم بعض عناصر الجودة (رقم الحامض، رقم البيروكسيد، الــرقم اليــودي، تركيــبـ

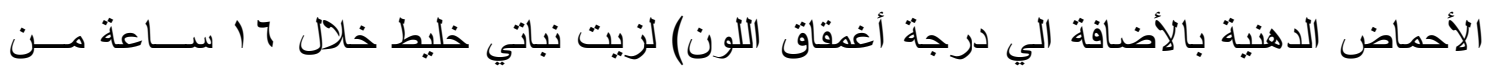

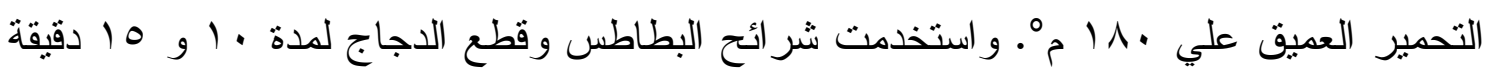

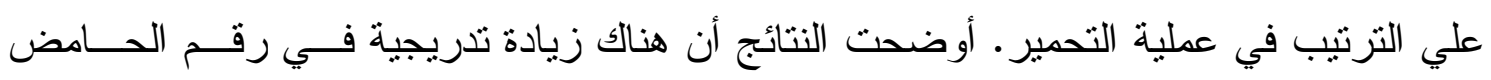

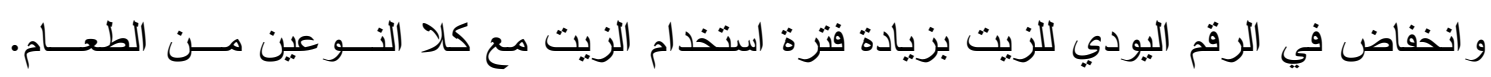

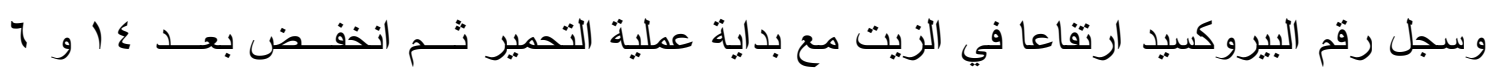

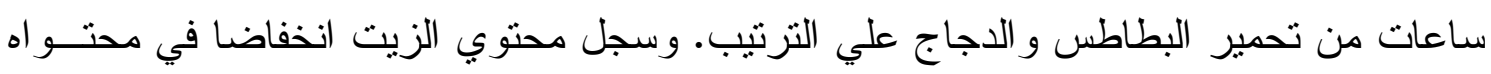
من مجموعة الأحماض الدهنية غير المشبعة مع زيادة في محتواه من الأحماض الدهنية المشبعة

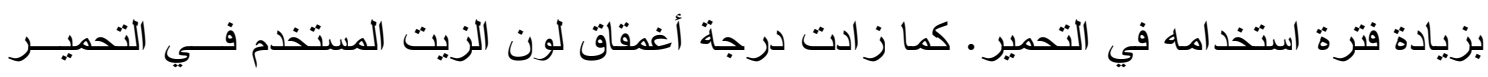

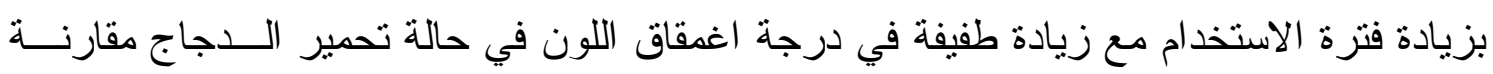
بتحمير البطاطس. 